\section{Advancing water resource management in agricultural, rural, and urbanizing watersheds: Why land-grant universities matter}

A.J. Gold, D. Parker, R.M. Waskom, J. Dobrowolski, M. O’Neill, P.M. Groffman, K. Addy, M. Barber, S. Batie, B. Benham, M. Bianchi, T. Blewett, C. Evensen, K. Farrell-Poe, C. Gardner, W. Graham, J. Harrison, T. Harter, J. Kushner, R. Lowrance, J. Lund, R. Mahler, M. McClaran, M. McFarland, D. Osmond, J. Pritchett, L. Prokopy, C. Rock, A. Shober, M. Silitonga, D. Swackhamer, J. Thurston, D. Todey, R. Turco, G. Vellidis, and L. Wright Morton

Federally funded university water programs have had limited success in halting the degradation of water resources in agricultural, rural, and urbanizing watersheds for the past five decades. USDA-funded university water programs have advanced our understanding of watershed processes and the development of best management practices (BMPs; e.g., conservation tillage, nutrient management, alternative and innovative septic systems, and riparian buffers) to mitigate environmental risks from anthropogenic activities, in particular from agriculture, to our water resources; yet water degradation persists and has worsened in many watersheds (Howarth et al. 2000; Mueller and Spahr 2006). The National Research Council (2012) stresses the need for sustainable agricultural practices to reduce changes in flow regimes and water quality.

In this research editorial, we make four points relative to solving water resource issues: (1) they are complex problems and difficult to solve; (2) some progress has been made on solving these issues; (3) external nonstationary drivers such as land use changes, climate change and variability, and shifts in markets, policies, and regulations warrant constant vigilance to assure that presumed improvements are being attained; and (4) we are poised to make substantial progress on these challenges over the next 10 to 20 years if critical steps are taken. Our discussion is framed by identifying and describing four grand challenges that we face in agricultural, rural, and urbanizing watersheds: nutrient management, food safety, agricultural water use, and groundwater management. These four grand challenge areas were distilled from a listing of over 50 resource management identified at a workshop of university and government water scientists in November of 2011. Our over-

Arthur J. Gold is a professor in the Department of Natural Resources Science at the University of Rhode Island, Kingston, Rhode Island. Doug for Water Resources at the University of California, Oakland, California. Reagan M. Waskom is the director of the Colorado Water Institute/ Water Center at Colorado State University, Fort Collins, Colorado. Jim Dobrowolski is a national program leader at USDA National Institute of Food and Agriculture, Washington, DC. Mike O'Neill is an associate dean and associate director at the University of Connecticut Cooperative Extension System, Storrs, Connecticut. Peter M. Groffman is a microbial ecologist a the Cary Institute of Ecosystem Studies, Millbrook, New York. Kelly Addy is a research associate in the College of Environment and Life Sciences at the University of Rhode Island, Kingston, Rhode Island. Michael Barber is a professor in the Department of Civil and Environmental Engineering, Washington State University, Pullman, Washington; Sandra Batie is a professor emeritus in the Department of Agricultural, Food, and Resource Economics, Michigan State University, East Lansing, Michigan; Brian Benham is an associate professor and extension specialist in the Department of Biological Systems Engineering, Virginia Polytechnic Institute, Blacksburg, Virginia; Mary Bianchi is a horticultural farm advisor at the University of California Cooperative Extension, San Luis Obispo, California; Tom Blewett is a professor in the Departimportant issues related to agricultural water Parker is the director of the California Institute ment of Engineering Professional Development at the University of Wisconsin-Madison, Madison, Wisconsin; Carl Evensen is a specialist in the Department of Natural Resources and Environmental Management at the University of Hawaii, Honolulu, Hawaii; Kitt Farrell-Poe is a water quality extension specialist and professor in the Agricultural and Biosystems Engineering Department at the University of Arizona, Tucson, Arizona; Cass Gardner is a professor at Florida A\&M University, Tallahassee, Florida; Wendy Graham is the Carl S. Swisher eminent scholar in Water Resources in the Department of Agricultural and Biological Engineering at the University of Florida and director of the University of Florida Water Institute, Gainesville, Florida; Joe Harrison is an animal scientist and extension specialist at Washington State University, Pullman, Washington; Thomas Harter is an extension groundwater hydrologist at the University of California Davis, Davis, California; Jennifer Kushner is an evaluation specialist at the University of Wisconsin-Madison, Madison, Wisconsin; Richard Lowrance is a research ecologist at the USDA Agricultural Research Service, Tifton, Georgia; Jay Lund is a professor and director of the Center for Watershed Sciences at the University of California Davis, Davis, California; Bob Mahler is a professor in the Environmental Science Program at the University of Idaho, Moscow, Idaho; Mitch McClaran is a professor in the School of Natural Resources and the Environment at the University of Arizona, Tucson, Arizona; Mark McFarland is a professor and extension specialist at Texas A\&M University, College Station, Texas; Deanna Osmond is a professor in the Department of Soil Science at North Carolina State University, Raleigh, North Carolina; James Pritchett is an associate professor in the Department of Agricultural and Resource Economics, Colorado State University, Fort Collins, Colorado; Linda Prokopy is an associate professor in the Department of Forestry and Natural Resources at Purdue University, West Lafayette, Indiana; Channah Rock is a water quality specialist and assistant professor at the University of Arizona, Maricopa, Arizona; Amy Shober is an assistant professor and extension specialist in the Department of Plant and Soil Sciences at the University of Delaware, Newark, Delaware; Maifan Silitonga is an associate professor at Kentucky State University, Frankfort, Kentucky; Deborah Swackhamer is a professor at the University of Minnesota, St. Paul, Minnesota; Jeannette Thurston is national program leader for the USDA National Institute of Food and Agriculture, Washington, DC; Dennis Todey is an extension state climatologist at South Dakota State University, Brookings, South Dakota; Ron Turco is a professor of agronomy at Purdue University, West Lafayette, Indiana; George Vellidis is a professor in the Department of Crop and Soil Sciences at University of Georgia, Tifton, Georgia; and Lois Wright Morton is a professor in the Department of Sociology, lowa State University, Ames, lowa. 
arching premise is that the combination of capacity in university-led research, extension, and education has the potential to enhance conservation planning, technical assistance, and research programs of the public and private sectors at the national, state, and local level and to galvanize significant progress on these challenges. The availability and focus of external funding will influence that progress by directing university investment in academic programs, faculty, and outreach.

How critical are these water problems? James R. Clapper, director of National Intelligence, in his 2012 statement of worldwide threat assessment noted,

Depleted and degraded groundwater can threaten food security and thereby risk internal, social disruption, which in turn, can lead to political disruption. When water available for agriculture is insufficient, agricultural workers lose their jobs and fewer crops are grown. As a result, there is a strong correlation between water available for agriculture and national GDP in countries with high levels of agricultural employment. (Clapper 2012)

Distinctions between "wicked" and "tame" problems have been made (Rittel and Webber 1973; Batie 2008). Wicked problems are hard to define, affect stakeholders in different ways, and therefore have no clear solutions. Water resource issues in agricultural, rural, and urbanizing watersheds are often wicked problems - they are complex and have led to a series of persistent negative outcomes: unsustainable use of water resources, widespread impairment of water quality, failure to meet specific water quality goals across heterogeneous spatial and temporal landscapes, continued use of farming practices known to contribute excess nutrients or other pollutants, and economic stress for producers.

The persistent nature of water resource problems in agricultural, rural, and urbanizing watersheds causes environmental scientists and managers to question current approaches to these problems. Yet it is important to remember that the persistence of complex problems does not necessarily mean that the actions taken are improper; it often just indicates that the problem is hard to solve and takes time far beyond the typical extramural grant period. For example, despite decades of education, tax disincentives, and regulations to reduce smoking, more than 1,000 people per day still die from cigarette use (US Department of Health and Human Services 2010). However, sustained declines in lung cancer deaths have occurred in some states. These declines are attributed in part to investments and cooperation between researchers, educators, voluntary organizations, and policy makers and include outreach that is culturally appropriate, engages community organizations, and targets highrisk populations (Bonnie et al. 2007). Here, we argue that the types of outreach and cooperation that contribute to smoking declines are in hand for water resource issues and that we will see marked improvements in the status of water resources and societal benefits if these tools can be integrated and applied over large areas. These marked improvements require the focus and strengths of academia, government agencies, and the private sector-in concert with stakeholder groups. Universities, particularly land-grant universities, have extensive outreach capacity in watersheds across America. They can access a spectrum of disciplines and expertise that is needed to solve these complex problems and contribute to the work of sister agencies, the private sector, and stakeholder organizations (see tables 1 and 2 for examples).

In the next sections, we describe the four grand challenges related to water resources in agricultural, rural, and urbanizing watersheds and point the way to addressing these problems with integrated programs of research, extension, and education. We see these four grand challenges in the context of external, nonstationary drivers that impact water resource management in these watersheds. We also advocate for four key approaches that must be integrated to help us move closer to solutions for these grand challenges (figure 1).

In describing the four grand challenges, we attempt to provide a brief description of the current situation and significance of the problem. We identify critical gaps in our current knowledge of the challenge and offer potential actions appropriate for universities and their partners or stakeholders that can result in marked improvements in the management, quality, and quantity of our nation's waters.

\section{Nonstationarity as a Driver for Water Management}

Land use changes (e.g., urbanization, changes in the extent or intensity of agricultural activity, and alterations within a drainage network); climate change and variability; and shifts in markets, policies, and regulations create a dynamic set of nonsta- tionary drivers that add complexity and risk to traditional approaches of managing agricultural, rural, and urbanizing watersheds (Kiang et al. 2011). World population is projected to grow from the current 7 billion to 9 to 10 billion by 2050 with demands for agricultural food production nearly doubling within this period.

Additional food, feed, fiber, and (bio) fuels will need to be produced and will thus necessarily lead to expansion and continued intensification of agriculture. Simultaneously, metropolitan areas in the United States have grown at unprecedented rates, creating extensive urban, urbanizing, and ex-urban landscapes from farmlands, wetlands, forests, and deserts. Some watersheds will experience more intensive urbanization (e.g., $10 \%$ to $30 \%$ of land area), putting enormous pressures on limited water supplies, increasing the risk of serious conflicts, and demanding a focus on solutions for mixed-use watersheds (Marcum 2006). Obvious sources of conflicts between urban and agricultural lands arise from competition for finite water supplies, differing valuation of ecosystem services by water and land resources, and impairment of drinking water resources at the urban-agricultural interface. However, urbanizing rural landscapes also impact watershed systems in ways that modify the functions of agricultural BMPs. They alter nutrient cycling, modify landforms and drainage networks, and perturb hydrologic systems (Alberti 2005). Sustaining and restoring water resources in agricultural, rural, and urbanizing watersheds requires a holistic approach that includes consideration of impacts that emerge from the pockets and fingers of urbanization or intensive agriculture that now characterize many areas once considered as rural. For example, intense runoff flow rates generated by upstream urban development can deepen stream channels, thereby lowering riparian water tables and diminishing the nitrogen $(\mathrm{N})$ abatement functions of riparian buffer zones for agricultural lands (Groffman et al. 2003). Another example is when offsite impacts from new, unsewered residential developments negate watershed improvements expected from investments in agricultural water pollution abatement practices (Gold et al. 1990).

Water management has long sought to reduce the impacts of temporal variations in weather patterns through advances in irrigation, conservation practices, cropping 


\section{Table 1}

Examples of university-led integrated research and extension projects.

\begin{tabular}{lll}
\hline Initiative & $\begin{array}{l}\text { Institutions } \\
\text { involved/Web site }\end{array}$ & Goal \\
\hline Coalbed & Montana State & The goal of the CBM-Regional \\
Methane & University, Univer- & Geographic Initiative is to guide \\
(CBM)- & sity of Wyoming, & landowners and agencies dealing \\
Regional & and Colorado & with domestic energy development \\
Geographic & State University & with minimal water quality impacts \\
Initiative & http://www. & in the Northern Plains and Moun- \\
& region8water.org & tains Region.
\end{tabular}

\section{Impacts and outcomes}

Through research and outreach efforts, project partners have

- educated landowners on the impacts of oil and gas development, split estate issues, and surface owner rights;

- developed a Land \& Water Inventory Guide for Landowners in Areas of CBM

Development and a public television documentary: Prairies and Pipelines;

- worked with the state of Montana, the Northern Cheyenne Tribe, and the US Environmental Protection Agency to adopt numeric surface water quality standards and water management regulations specifically dealing with CBM-produced water;

- established narrative water quality standards with Wyoming regulators;

- promulgated rules and permitting protocols specific to CBM-produced water with Colorado regulatory agencies; and

- modified CBM water discharge permit processes of Wyoming and Montana Environmental Quality departments to protect existing beneficial water uses.

\section{Nitrate in University of}

Drinking California, Davis

Water

\section{http://groundwa-}

ternitrate.ucdavis.

edu University of

California,

Agriculture and

Natural Resources

http://ucanr.edu/

News/Healthy_

crops,_safe_water

The goal of the Nitrate in Drinking

Water program is to minimize nitrate

$\left(\mathrm{NO}_{3}\right)$ contamination problems in

California. University of California

researchers have established a

broad, interdisciplinary assessment

of $\mathrm{NO}_{3}$ sources, groundwater $\mathrm{NO}_{3}$

status, and drinking water solu-

tions. Researchers and extension

agents are working with growers on

fertilizer management, irrigation

efficiency, and other farming prac-

tices to protect groundwater; with

regulatory and stakeholder agencies

on developing regulatory and grant

programs; and with communities on

improved drinking water solutions.
Activities have established

- a report to the legislature, "Addressing Nitrate in California's Drinking Water;"

- forums on farmers' efforts, exploring additional solutions to protect groundwater quality and engaging the agricultural community on what additional research and education is needed from University of California;

- executive level interagency and stakeholder workgroup at the governor's office;

- development and implementation of regulatory framework and monitoring programs for agricultural $\mathrm{NO}_{3}$ and salt discharges to groundwater and surface water; and

- research projects to develop best management practices protective of groundwater quality.
Livestock University of Georand Poultry gia, Washington Environ- State University, mental and University of Learning Nebraska http:// Center www.extension. (LPELC) org/animal_manure_management
The goal of the LPELC is to improve and protect water quality by connecting researchers, regulators, extension, and educators with animal producers and their advisors.

Through research and outreach efforts, the project's partners have

- collaborated with several projects and programs to increase animal agriculture access to research-based information;

- developed an extension community of practice;

- undertaken extensive social media outreach and monthly webcasts (>40 archived webcasts)-participants in these webcasts have influenced over 180,000 producers per year; and

- created a newsletter with subscribers (over 1,500) who shared (April 2008 survey) that LPELC resources contribute to significant or moderate improvements in application of emerging technologies (65\%), to increased value from manure utilization (57\%), to policy development (49\%), and to advice for animal producers (69\%).

Rio Grande Texas A\&M UniBasin Initia- versity and New tive (RGBI) Mexico State University http:// riogrande.tamu. edu/
The goal of the RGBI is to implement strategies for meeting water demands in the Rio Grande Basin. Researchers and Extension agents worked with local irrigation districts, agricultural producers, homeowners, and regional agencies to meet present and future water demands through water conservation and efficient irrigation measures.
Through research and outreach efforts, the project's partners have

- conducted an economic assessment of citrus irrigation strategies;

- provided educational programs on rainwater harvesting that have led to new demonstrations and home installations;

- helped irrigation districts install $42 \mathrm{~km}$ (26 mi) of synthetic canal lining materials; - tracked long-term effectiveness and durability of canal lining materials; and - demonstrated that grass carp has reduced or eliminated submerged aquatic vegetation from irrigation canals, with estimated savings of more than US $\$ 500,000 \mathrm{y}^{-1}$. 
Table 1 continued

Examples of university-led integrated research and extension projects.

\begin{tabular}{|c|c|c|c|}
\hline Initiative & $\begin{array}{l}\text { Institutions } \\
\text { involved/Web site }\end{array}$ & Goal & Impacts and outcomes \\
\hline $\begin{array}{l}\text { Heartland } \\
\text { Manure } \\
\text { Management } \\
\text { Program }\end{array}$ & $\begin{array}{l}\text { Kansas State } \\
\text { University, lowa } \\
\text { State University, } \\
\text { University of Mis- } \\
\text { souri-Columbia, } \\
\text { and University of } \\
\text { Nebraska-Lincoln } \\
\text { http://www.heart- } \\
\text { landwq.iastate. } \\
\text { edu/ManureMan- } \\
\text { agement }\end{array}$ & $\begin{array}{l}\text { The Heartland Manure Manage- } \\
\text { ment initiative's primary goal is to } \\
\text { incorporate land-grant university } \\
\text { research with extension client- } \\
\text { focused priorities into a manure } \\
\text { nutrient management plan frame- } \\
\text { work to protect water quality that } \\
\text { will allow livestock operations to } \\
\text { comply with regulatory mandates } \\
\text { for environmental manure manage- } \\
\text { ment while also remaining flexible } \\
\text { and profitable. }\end{array}$ & $\begin{array}{l}\text { Through research and outreach efforts, the project's partners have } \\
\text { - engaged the regulatory community in both integration of science } \\
\text { and review of implementation policies for the nutrient management } \\
\text { plan component of the concentrated animal feeding operation rule; } \\
\text { - developed a narrative approach placing methodologies and proto- } \\
\text { cols in a strategic and annual outline to serve both regulatory pur- } \\
\text { poses and a farm's operational management-which was included in } \\
\text { the final revised concentrated animal feeding operation rule; and } \\
\text { - developed an online narrative National Pollutant Discharge Elimi- } \\
\text { nation System Nutrient Plan, which the US Environmental Protection } \\
\text { Agency used as a training model for the "EPA Permit Writers and } \\
\text { Inspectors Training." }\end{array}$ \\
\hline
\end{tabular}

systems, flood plain mapping, and water table management. New insights into the extent and patterns of climate change and climate variability - in a nonstationary climate-demand renewed attention to the policies and practices that can reduce risks to water availability and nonpoint source water pollution (Brown et al. 2010; Kiang et al. 2011). The Executive Summary of the 2008 Intergovernmental Panel on Climate Change Report states, "Current water management practices may not be robust enough to cope with the impacts of climate change on water supply, reliability, flood risk, health, agriculture, energy, and aquatic ecosystems" (Bates 2008). Agricultural producers, rural communities, and policy makers require insights that highlight water-related risks from an uncertain future and provide approaches that can build resilience and adaptability into watershed management (Delgado et al. 2011; Lal et al. 2011).

Meeting environmental goals, while continuing to enhance economic growth in agriculture, will require an increased focus on the roles of policy and economics on water resource management. Government policies (e.g., regulatory authorities, conservation programs, and price supports) and economics (e.g., shifting markets and prices) exert considerable influence on farmers' and ranchers' decisions to participate in government programs or adopt conservation practices to protect or enhance water resources. These influences often lead to conflicting management options for producers (Green and Hamilton 2000; Schaible 2000).

Each of the four grand challenges highlighted in this paper have unique responses to these drivers. However, interactions among the drivers and complex responses among the four grand challenges are likely to mask progress toward solutions. Improving our understanding of the interactions among the drivers and the grand challenges is critical to moving society closer to solutions for these complex water problems and is central to evaluating progress on these challenges.

\section{Grand Challenge 1: Nutrients and Water Quality}

Situation and Significance. Increased fertilizer use and improved crop varieties that can better utilize nutrients are strongly linked to the huge gains in food production that the world has witnessed over the past 50 years (Tilman et al. 2002). However, the increases in fertilizer applications have come with unintended consequences, with pronounced elevations in $\mathrm{N}$ and phosphorus $(\mathrm{P})$ concentrations in streams and groundwater in areas where agriculture is a substantial land use (Dubrovsky et al. 2010). These excess nutrients increase algal biomass in freshwater and estuaries, leading to anthropogenic eutrophication characterized by loss of fisheries and spawning habitats, "dead zones" of oxygen-depleted bottom waters, and harmful algal blooms (Conley et al. 2009; Howarth et al. 2000). Phosphorusinduced blue-green algae blooms-and the associated public health threat from their neurotoxins - are increasingly found within local ponds in the agricultural regions of the Midwest (Graham et al. 2004). Croplands are also the leading cause of groundwater pollution from nitrate-N $\left(\mathrm{NO}_{3}-\mathrm{N}\right)$, a drinking water contaminant (Nolan et al. 2002), and can be sources of air quality degradation and greenhouse gases (Cowling et al. 1998; Sutton et al. 2012).

Curtailing nutrient losses from agricultural lands is a hallmark of watershed initiatives in all parts of the nation-from regionally significant waters, like the Chesapeake Bay, the Gulf of Mexico, or the California Central Valley aquifer system, to local freshwater ponds. In recognition of the environmental consequences of excess nutrients, the United Nations Environmental Program has initiated the Global Partnership for Nutrient Management with a strong focus on rural and agricultural lands. With global populations expected to increase by almost $33 \%$ by 2050 (UN DESA 2010), the United States and all agricultural nations are faced with the challenge of increasing food production while reducing losses of $\mathrm{N}$ and $\mathrm{P}$ to ground and surface waters. As with other agricultural water challenges, substantial progress depends upon developing a system of interlocking initiatives based on deep knowledge of hydrology, nutrient cycling, cropping systems, human behavior, economics, and policy to provide tractable solutions for the diverse array of rural and agricultural conditions.

Knowledge Gaps. Groffman et al. (2010) argue that we need to "connect the dots" between "sources," areas with a high likelihood of nutrient losses at the field edge or bottom of the root zone, and "sinks," areas within watersheds that remove nutrients such as wetlands, lakes, and riparian zones. The effort requires research, assessment, and management at the watershed, farm, and field scales.

Actions and Outcomes. At the watershed scale, we suggest that nutrient management efforts start with strategic targeting of high nutrient-delivery agricultural lands and unsewered developments through watershed-scale analyses. The outcomes of new research, development, and extension efforts must include the following: 
- Increasing the capacity of county agents, conservationists, and farmers to prioritize source controls to critical areas with high risks of nutrient delivery to groundwater and surface waters (Kellogg et al. 2010)

- Developing and using more accurate and usable models based on high resolution geospatial data that tailor results to the unique and varied climate, cropping systems, soils, and watershed features that characterize America's rural lands (Delgado and Berry 2008)

- Committing to long-term, controlled watershed experiments-at scales that permit scientists to unravel the many factors, including climate variability, that affect the fate and transport of nutrients from source and sink locations-to generate accurate watershed models

At the farm scale, nutrient management must be integrated with water management to link sources with sinks for the economic benefit of the entire farm enterprise. Farmscale research and extension should contain the following elements:

- Considering crop selection, water reuse, management of buffers for multiple environmental benefits, and reintegration of animal and plant production through manure management and watershed-based nutrient budgets.

- Developing and implementing on-farm BMPs where management, cropping systems, drainage, or other field conditions generate high risks of edge-of-field losses. Examples include riparian zones, controlled drainage, carbon (C) bioreactors, or constructed wetlands that can capture and remove nutrients before they enter downstream waters.

- Incorporating these practices into holistic farm management programs that tailor and optimize on-farm water and nutrient management based on site conditions and enhance functional and sustained practice adoption.

At the field scale, research and extension are needed to generate marked improvements in nutrient use efficiency, including the following:

- Understanding and assessing interactions among cropping systems, weather, and site characteristics to optimize production while reducing nutrient loss ( $\mathrm{Li}$ et al. 2007; Delgado et al. 2001). The effects of advancements in crop genetics, cropping systems, and geospatial field management on plant nutrition warrant recalibration of soil test recommendations to optimize yields while reducing offsite nutrient losses.

- Understanding and incorporating methods of communication and factors that trigger - and sustain - behavioral change.

- Researching and promoting decision support tools, through apps or online models. We are on the verge of empowering large numbers of farmers with real-time, spatially explicit management recommendations that incorporate the effects of planting date, crop variety, recent weather, fertilization regimes, cropping history, and spatial pattern of soils and hydrology.

Regional and interregional scale solutions may be required to address nutrient imbalances between crop production regions and regions with extensive animal production. These will require research and extension on policies, economics, and market development in addition to the technology surrounding stabilization and transport of manure. Correcting these imbalances warrants creative interregional solutions that may entail the development of nutrient markets that reconnect animal production regions with crop production regions. The development of social indicators among stakeholders may also help in regional resource management programs (Genskow and Prokopy 2010).

\section{Grand Challenge 2: Food Safety and Water} Situation and Significance. Foodborne pathogens and other contaminants lead to an estimated 47 million illnesses and 3,000 deaths each year in the United States (Scallan et al. 2011a). Of the 31 known foodborne pathogens, at least 26 can be transmitted via water and are responsible for 9.4 million illnesses and 1,351 deaths within the United States (Scallan et al. 2011b). In order to reduce foodborne illness while maintaining economic and environmental sustainability, government, academia, industry, and other stakeholders need to work together to develop solutions that ensure food safety and promote healthy environments.

Knowledge Gaps. There continues to be substantial gaps in knowledge, including basic information on the occurrence, fate, and public health impacts of waterborne contaminants within the food chain, including pathogens, pesticides, and nutrients. Examples of water suspected as a source of food contamination include irrigation water
(Nguyen-The and Carlin 2000), application of fungicides/pesticides (Herwaldt and Ackers 1997), cooling system water (CDC 1999), washwater (Beuchat 1996), and harvesting waters (Morris 2011). Contaminated water can also come in contact with food or water supplies through heavy rain or snow melt events which produce runoff from contaminated land (Thurston-Enriquez et al. 2005). Animal drinking water troughs in confined animal facilities can serve as longterm reservoirs of zoonotic pathogens and a source of infection to livestock, as has been shown for Escherichia coli O157:H7 (LeJeune et al.2001).Additionally, some on-farm practices noted to be important in addressing the nutrient management grand challenges, including wetlands, riparian zones, and vegetated buffers, have the potential to attract wildlife and increase fecal contamination in adjacent crops (Lowell et al. 2010). The transient nature of water along with ineffective sampling strategies makes identifying water as a source of foodborne contaminants extremely difficult. Studies to identify contaminants transmitted by water are needed along with understanding their fate within the food chain.

Actions and Outcomes. The intersection of water quality protection and safe food supply maintenance is a complex problem that involves a myriad of economic, social, management, environmental, legal, and policy issues. Many research programs are focused on foodborne contaminants in food; this research should be augmented by the following work:

- Studying the impacts of water quality management practices on potential fecal contamination from domestic and wild animals, pathogen persistence in irrigation tailwater, sediments from irrigation, and sediment control structures. For example, vegetable growers report finding themselves in an untenable position-pressured to minimize the use of on-farm practices that promote water quality in order to address concerns of food safety professionals (Lowell et al. 2010).

- Considering comanagement approaches (Lowell et al. 2010) that rely on management practices, such as buried bioreactors (Schipper et al. 2010), to minimize animal vectors of microbial hazards and still afford water quality protection.

- Examining the occurrence, fate, and transmission of waterborne contaminants. 
Table 2

Example conservation issues and university response efforts and outcomes.

\begin{tabular}{|c|c|c|c|}
\hline Project & Situation & University response & On-the-ground results \\
\hline $\begin{array}{l}\text { Neuse Edu- } \\
\text { cation Team: } \\
\text { enhancing } \\
\text { farmer } \\
\text { adoption } \\
\text { of nutrient } \\
\text { management } \\
\text { to decrease } \\
\text { watershed ni- } \\
\text { trogen losses } \\
\text { (summarized } \\
\text { from Osmond } \\
\text { et al. 2010) }\end{array}$ & $\begin{array}{l}\text { Due to massive fish kills, harmful algal blooms, } \\
\text { and public perception of declining water quality, } \\
\text { the North Carolina Environmental Management } \\
\text { Commission implemented the Neuse Rules to } \\
\text { reduce annual nitrogen ( } \mathrm{N} \text { ) loading to the Neuse } \\
\text { River by } 30 \% \text {. As agricultural land uses contrib- } \\
\text { uted approximately half of the N loading to the } \\
\text { Neuse River, agriculture was targeted heavily by } \\
\text { the Neuse Rules. Any farmers applying nutrients } \\
\text { to } 20 \text { ha (50 ac) or more had to either use a certi- } \\
\text { fied nutrient management plan or attend nutrient } \\
\text { management training. In addition, farmers were } \\
\text { required to use an N tracking and accounting } \\
\text { tool-a tool that had yet to be developed at the } \\
\text { initiation of the Neuse Rules. While a suite of } \\
\text { best management practices have been docu- } \\
\text { mented by scientists to reduce farm losses of } \\
\mathrm{N} \text {, there was a communication gap between the } \\
\text { scientists and the farmers on how to best select } \\
\text { and implement the appropriate strategies at the } \\
\text { individual farm level and generate a certified nu- } \\
\text { trient management plan. }\end{array}$ & $\begin{array}{l}\text { A group of cooperative extension specialists and agents } \\
\text { based at North Carolina State University formed the } \\
\text { Neuse Education Team to bring science-based informa- } \\
\text { tion to inform farmer decisions in reducing farm-level } \\
\mathrm{N} \text { losses to the Neuse River Basin. A comprehensive } \\
\text { nutrient management training program targeting farm- } \\
\text { ers and agribusiness professionals was created and } \\
\text { delivered by the Neuse Education Team in response } \\
\text { to stakeholder assessments. In addition, the Neuse } \\
\text { Education Team, with their close ties to university sci- } \\
\text { entists, led the development and application of the N } \\
\text { tracking tool, the Nitrogen Loss Estimation Worksheet } \\
\text { (NLEW) (Osmond et al. 2001a, 2001b). Local farmers } \\
\text { used NLEW to track nutrient management implementa- } \\
\text { tion and N controls. }\end{array}$ & $\begin{array}{l}\text { Results from pretraining } \\
\text { and posttraining evalua- } \\
\text { tions of farmers indicated } \\
\text { that there was an improve- } \\
\text { ment in the understanding } \\
\text { of nutrient management } \\
\text { and pollution issues. } \\
\text { Through farmer use of } \\
\text { NLEW, research deficits } \\
\text { were identified which } \\
\text { spurred additional re- } \\
\text { search projects to address } \\
\text { edge-of-field N losses, } \\
\text { and improvements were } \\
\text { made to the NLEW tool } \\
\text { itself to improve N credits } \\
\text { (Smith et al. 2006). One } \\
\text { conclusion drawn from the } \\
\text { Neuse Education Team } \\
\text { was that real changes } \\
\text { in environmental quality } \\
\text { require a comprehensive } \\
\text { effort of education, regula- } \\
\text { tion, and incentives. }\end{array}$ \\
\hline
\end{tabular}

Alternative In the continental United States, approximately and innovative septic systems: economic vitality and environmental health for rural America $25 \%$ of households rely on onsite wastewater treatment systems, commonly referred to as septic systems. The siting, design, and performance of these systems are most often the responsibility of officials who manage public and environmental health in rural and urbanizing counties (Joubert et al. 2004). Poorly functioning septic systems generate pathogens and nutrients that degrade lakes, estuaries, and drinking water aquifers. Failing systems threaten public and environmental health and can constrain economic development in nonurban counties. In certain settings, such as seasonal shoreline developments or aquifer recharge zones, even well-maintained conventional septic systems fail to provide adequate protection for receiving waters (Postma et al. 1992).
In the past 15 years, an array of innovative and alternative treatment systems have been developed and tested by university researchers and the public and private sectors. $A$ varied set of design configurations are now widely used to reduce environmental and public health risks (Amador et al. 2008; Oakley et al. 2010). In water-limited locations, grey water (household wastewater exclusive of toilet waste) effluent is treated and applied as irrigation to supplemental landscape irrigation (Waskom and Kallenger 2009).

However, these new designs alone do not solve the water quality problems of onsite wastewater treatment. University Cooperative Extension programs across the nation have developed a coordinated education and training program to assure that the adoption of these new technologies moves forward in an informed fashion. University-based Onsite Wastewater Training Centers have been established that serve as regional hubs to extend the technologies and required management to stakeholders. These Centers showcase best available practice wastewater treatment designs appropriate for the range of geological and environmental conditions in their region. The Centers develop and deliver stateof-the-art educational curricula, including workshops, hands-on practical training sessions, and technical manuals to thousands of locally based wastewater practitioners, policy makers, and the public on septic system issues. The extension network works closely with public health officials to improve their design standards and provides targeted training to the private sector that prepare them for those certifications and licensing tests now required of those engaged in the business.
The Centers bring alternative wastewater treatment systems to the attention of communities, professionals, and regulators. Thousands of professionals have been trained and certified, consequently applying their knowledge and skills at the local level. Local wastewater management plans were developed and local ordinances changed. These efforts are reflected both regionally and nationally by the improvement and protection of water quality from wastewater contamination. 


\section{Table 2 continued}

Example conservation issues and university response efforts and outcomes.

\begin{tabular}{|c|c|c|c|}
\hline Project & Situation & University response & On-the-ground results \\
\hline $\begin{array}{l}\text { University } \\
\text { action on } \\
\text { agricultural } \\
\text { water con- } \\
\text { servation }\end{array}$ & $\begin{array}{l}\text { Population growth and climate variability } \\
\text { are putting increasing pressure on lim- } \\
\text { ited water resources. While agriculture } \\
\text { accounts for over } 70 \% \text { of the water } \\
\text { used in the United States, it is also esti- } \\
\text { mated that agricultural water shortages } \\
\text { have cost US agriculture US } \$ 4 \text { billion } \\
\mathrm{y}^{-1} \text { (WEF } 2009 \text { ). Water demands from } \\
\text { urban growth and increases in crop con- } \\
\text { sumptive use must be accommodated } \\
\text { by timely improvements in agricultural } \\
\text { water delivery, management practices, } \\
\text { and technology (Strzepeck et al. 1999). }\end{array}$ & $\begin{array}{l}\text { University-led research is underway to determine the best } \\
\text { methods to optimize agricultural water use and to better un- } \\
\text { derstand how to market agricultural water to other uses, both } \\
\text { without compromising agricultural profitability and production } \\
\text { in the long run. Current research partnerships with municipal } \\
\text { water providers, corporate partners, nongovernmental organi- } \\
\text { zations, and USDA are developing decision tools and analyzing } \\
\text { various institutional arrangements to optimize water markets } \\
\text { and short-term lease arrangements. Additional university part- } \\
\text { nerships with USDA Agricultural Research Service are develop- } \\
\text { ing advances in irrigation application, evapotranspiration and } \\
\text { soil moisture measurement, and remote sensing to provide the } \\
\text { technological bases for enhancing water productivity. The USDA } \\
\text { National Institute of Food and Agriculture Northern Plains and } \\
\text { Mountains Regional Water Team (land-grant university-based) } \\
\text { developed the Agricultural Water Conservation Clearinghouse } \\
\text { (AWcC } 2013 \text { ) to translate research-based information and tools } \\
\text { for water managers, irrigators, and policy makers in order to } \\
\text { increase understanding and adoption of agricultural water con- } \\
\text { servation and protection. } \\
\text { The Northern Plains and Mountains Regional Water Team } \\
\text { has also focused on increasing the knowledge level of private } \\
\text { consultants, certified professional agronomists and soil sci- } \\
\text { entists, and agency personnel that influence grower decision } \\
\text { making. University water quality specialists authored and pub- } \\
\text { lished a series of online, self-study modules for the American } \\
\text { Society of Agronomy Certified Crop Advisor Recertification and } \\
\text { Proficiency Program. }\end{array}$ & $\begin{array}{l}\text { Research has enhanced } \\
\text { our ability to improve } \\
\text { agricultural water conser- } \\
\text { vation, and its translation } \\
\text { to agricultural decision } \\
\text { makers has increased the } \\
\text { adoption of these strate- } \\
\text { gies. To date, over } 5,600 \\
\text { bibliographic records have } \\
\text { been added to the Agricul- } \\
\text { tural Water Conservation } \\
\text { Clearinghouse, the library } \\
\text { has been searched by } \\
\text { over } 24,000 \text { users since it } \\
\text { was unveiled in } 2008 \text {, and } \\
\text { participation continues } \\
\text { to grow. Since the fall of } \\
2009 \text {, over } 550 \text { individu- } \\
\text { als have completed and } \\
\text { passed the self-study } \\
\text { modules. Over } 89 \% \text { of } \\
\text { ccAs completing post } \\
\text { module surveys indicated } \\
\text { they would utilize knowl- } \\
\text { edge gained from the } \\
\text { series while advising their } \\
\text { farming clients. }\end{array}$ \\
\hline
\end{tabular}

- Quantifying levels of uncertainty surrounding the potential for foodborne contamination. Lack of certainty regarding benefits of water quality practices also presents challenges (Lowell and Bianchi 2011).

University extension scientists have an opportunity to situate themselves as extenders of new knowledge, intermediaries, and catalysts between the practice-based and transissue communities involved in food safety, food safety certification, and water resources management. Extension scientists can inform stakeholders on these important issues in order to elaborate and expand partially shared understandings and projects. Additional research and extension work that would be valuable to food safety includes the following:

- Understanding how to communicate the risks, uncertainty, and legal implications to stakeholders. Engaging or creating communities eager for research that informs them about food safety risks (Bartley and Smith 2010).

- Helping landowners navigate new food safety rules. For example, under the 2011 Food Safety Modernization Act, the Food and Drug Administration will be issuing a number of rules, including a preventative controls rule in food facilities, a foreign supplier verification rule, and a national produce safety rule.

- Establishing transdisciplinary research and extension teams that address both food safety and water quality protection will help to solve the complex and interrelated issues that impact the safety of the nation's food supply. Gathering and communicating interdisciplinary-based information will help communities make balanced and informed decisions.

\section{Grand Challenge 3: Optimizing Water for Food and the Environment}

Situation and Significance. Water for food production will only continue to grow in global importance over time (Tilman et al. 2002). Scarce water already limits agricultural productivity and threatens the economy as population growth and attendant needs for new sources of energy pressure finite supplies (de Fraiture et al. 2008). The World Economic Forum predicts increased demand for water through 2030 by industrial and domestic use will crowd out any growth in agricultural water use (WEF 2011).

Water quality impairments of receiving waters further constrain agriculture. Freshwater ecosystems, already impaired in many basins, will be increasingly threatened according to climate projections, requiring more water for environmental flows. Stewarding threatened and endangered species can disrupt agricultural diversions at critical times during the cropping season when producers are most at risk. We must grow more food with less water and reduce the environmental impact of agriculture on downstream watersheds and ecosystems (Postel et al. 1996; Tilman et al. 2002).

The full promise of biotechnology and genomic innovation for water efficiency has been slow to develop, while our water problems require immediate attention. Many technological advances needed for water optimization in agriculture are already in hand, for example, more efficient irrigation systems; soil, water, and evapotranspiration monitoring and information systems; water reuse; and cropping systems that have been designed to capture and optimize precipi- 


\section{Figure 1}

External drivers, grand challenges, and key university-based approaches needed to make significant progress on agricultural water problems.

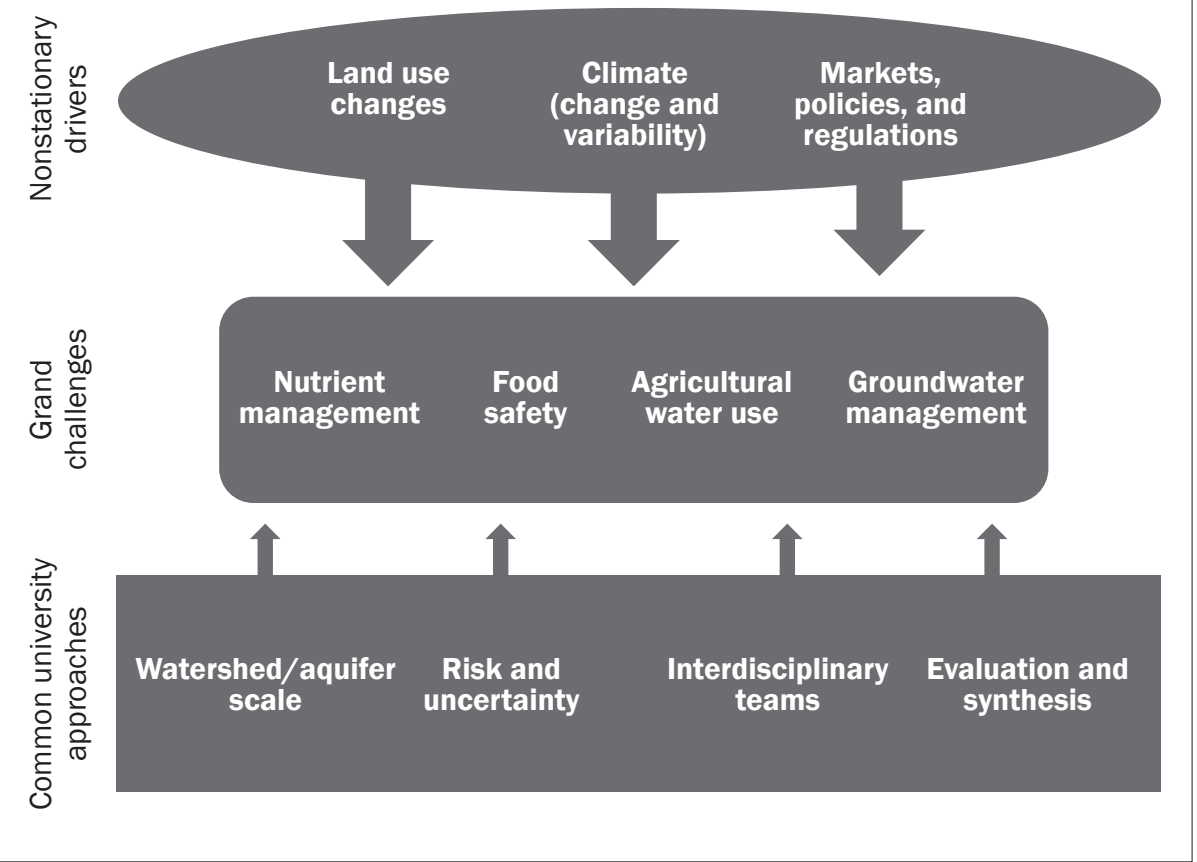

tation efficiency. It is often the institutional (i.e., surface vs. groundwater extraction rights), economic, and social norms that constrain adoption.

Knowledge Gaps. In simple terms, optimizing agricultural water use involves growing more food while reducing agriculture's environmental and water quality footprint. Agricultural water management must address competing demands from urban development, energy, and ecosystem services, while also addressing water quality sustainability. What is new in this approach is the coupling of agriculture and the environment as an integrated system, rather than separating these sectors as distinct problems or disciplines. A much greater focus on creating integrated data and information systems to support decision making is needed, along with understanding of cross-sector tradeoffs. The following actions and outcomes represent areas of critical investment.

Actions and Outcomes. To enhance the resilience and productive capacity of water, agricultural systems need to be adapted to an uncertain and nonstationary world with evolving food preferences. University-led actions for increasing resilience and adaptive capacity can include the following:

- Assessing available water resource data and integrating these data into existing models with important environmental flow, socioeconomic, and institutional information. These newer models articulate tradeoffs in agricultural productivity, ecosystem services and economic activity of proposed sharing mechanisms. They incorporate groundwater and surface water systems into a seamless model of the watershed/basin. Models can evolve into adaptive management tools for stakeholders and communication tools for educators (Meinke et al. 2009).

- Defining the knowledge gaps for agricultural system resilience in a participatory process with an assortment of stakeholders and policymakers. Through this process, dialogue will be facilitated among stakeholders, and tradeoffs associated with water resource policy will be effectively communicated.

- Exploring and evaluating approaches to manage water optimally within both rain-fed and irrigated landscapes while reducing environmental water quality impacts. Water use efficiency, productivity, and effective drainage are highlighted in this task.

To develop mechanisms and institutions for sharing amongst agriculture, urban, and environmental water, university research and outreach can provide insights and tools for

- Quantifying agricultural water value in its myriad of consumptive and non- consumptive uses, including for crop production, allied economic activity in the watershed, instream flow values, recreation, and aesthetic values.

- Increasing the use of wastewater recycling for irrigation of both urbanized landscapes and adjacent agriculture (Dobrowolski et al. 2008). Recycled water offers a drought-resistant, novel irrigation source with water quality dependent on current and future treatment technologies. The current challenge for research is to understand the effects of continued application of recycled water on soil health, crop bioaccumulation, and food safety (Anderson et al. 2010). University extension can help develop, test, and implement the outreach methodologies that promote behavior change and acceptance of recycled water use (Robinson et al. 2005).

- Increasing the adoption of BMPs by stakeholders by identifying and overcoming barriers to behavior change and implementation.

Agriculture is an important economic engine for the United States that can provide much needed ecosystem services, but we must optimize water use and protection in an integrated approach that simultaneously considers the environment, urban demands, and agriculture. A portfolio of solutions and tools are needed and effort must be directed at concrete outcomes with measurable impacts by intertwining scientific disciplines and agencies in watersheds.

\section{Grand Challenge 4: The Importance of Groundwater to Agricultural Lands and Rural Communities}

Situation and Significance. In 2000, the US Geological Survey estimated groundwater withdrawals in the United States to be 1,544 billion $\mathrm{L} \mathrm{d}^{-1}$ (408 billion gal day ${ }^{-1}$ ), representing a nearly $15 \%$ increase over the 1985 estimate with agricultural uses accounting for over $60 \%$ of the demand (Hutson et al. 2000). Thus, the social, cultural, and economic viabilities of rural communities across the United States are directly linked to the availability of safe and affordable water resources from both groundwater and surface water supplies. While both are tightly linked components of the hydrologic water balance, groundwater and surface water have historically been thought of as distinctive sources in terms of public perception and 
legal framework (Winter et al. 1998). Unlike surface water supplies where flooding, depletion, and contamination problems are readily apparent, groundwater problems may take years or decades to manifest themselves into recognizable concerns (Custodio 2003). This trend has historically led to a relaxed attitude regarding groundwater even though systematic depletion of aquifers, such as the High Plains Aquifer in the central United States, has long been documented (Emerson 1984; Sophocleous 2010). However, through national and regional assessments like the US Geological Survey National Water Quality Assessment Program, there is a growing recognition of problems associated with falling groundwater tables, increased drinking water contamination, and irrigation water salinization. Also, a better understanding of the linkage between groundwater and surface water resources has motivated a search for cost-effective solutions (Hunter 2008; Vecchia et al. 2009; Feaga et al. 2010; Liao et al. 2012).

As farmers look for new ways to increase agricultural production to feed a growing population while minimizing the risks associated with climate variability and adverse impacts on the environment, additional strains are being placed on groundwater (Scibek and Allen 2006; Waskom et al. 2006). In many areas, pressure on groundwater stocks are increasing as rural and urbanizing landscapes undergo increased development (Konikow and Kendy 2005; Levi and Sperry 2007).

Knowledge Gaps. Effectively managing groundwater requires better understanding of recharge, contaminant fate and transport, and interaction between groundwater and streams (Alley et al. 2002) as well as improved communication of unbiased information to the public and decision makers (Kemper 2003; Mahler et al. 2005). Our demands for both precision and accuracy require improved techniques for quantifying impacts of groundwater withdrawals at the watershed scale and a better understanding of the complex interactions between land use, groundwater quantity, groundwater quality, and groundwater/surface water by stakeholders, decision makers, and scientists (Akbar et al. 2011). This need is difficult to address in rural communities due to the costs associated with the data collection, modeling, and interpretation that characterize thorough subsurface investigation programs. Improved monitoring techniques, assessment tools, and agricultural practices are needed to reduce expenses while providing reliable prediction of groundwater/surface water responses to management decisions (Barber et al. 2009). Research and outreach must recognize that groundwater is a significant component of the overall water balance of nearly any watershed. It can serve as the basis for additional studies that recognize critical groundwater quantity and quality research needs that must be addressed to optimally manage water resources.

Actions and Outcomes. Investments in both physical and cyber infrastructure are needed to improve measurement of aquifer properties as well as the storing and sharing of data. Coupled with applied groundwater research, education, and outreach, this information will enable development of new tools capable of addressing water availability and reliability. University research focused on the groundwater challenge should include the following:

- Inventorying groundwater quantity and quality that produces a consistent national database of aquifer information in an easily retrievable web-based archive system, such as the National Science Foundationsponsored Consortium of Universities for the Advancement of Hydrologic Science Inc., Hydrologic Information System. Databases across aquifers and watersheds should be integrated.

- Analyzing the role of agricultural landscapes in groundwater recharge and conjunctive water management. Transparent information about local, regional, and national groundwater use should be made available.

- Assessing groundwater science at appropriate and diverse scales while characterizing and mapping aquifer properties, such as depth, flowpaths, and travel times.

- Improving life cycle protocols including groundwater emissions and leaching from agricultural BMPs, developing new techniques for irrigation that minimize ecosystem and water quality impacts, and formulating mitigation strategies implementable at a range of scales.

Involvement of university extension will foster improved community-based decision making with respect to the use of groundwater resources across agricultural, rural, and urbanizing landscapes that allows for optimum and sustainable economic development while protecting human and ecosystem health. In particular, university extension can contribute by

- Developing extension activities for private well owners aimed at locating, testing, and fixing private wells

- Engaging the community and state water management agencies in aquifer-specific studies and advancing the use of userfriendly tools that allow stakeholder and decision maker evaluation of alternatives while also considering the economic implications of groundwater quantity and quality conservation

\section{Common University-Based Approaches: Revisiting the Solutions}

The challenges described in this document are not new to agricultural research, education, and extension. In fact, a considerable amount of literature exists on each of these topics. However, to accelerate positive changes on agricultural water resource management, we have identified the following four key approaches that must be incorporated in future university programs:

- Focus problem solving and practices for stakeholders at watershed or aquifer scales

- Incorporate risk and uncertainty into decision support strategies

- Engage interdisciplinary teams that can couple insights from natural sciences, engineering, and social sciences with advances in behavioral change, incentives, policies, and communication

- Evaluate progress, synthesize findings, communicate solutions, and adapt approaches to implementation that are based on feedback loops

Focus Problem Solving and Practices at Watershed or Aquifer Scales. Within every watershed and farm enterprise, solutions must be tailored to the unique local blend of climate, soils, hydrology, cropping systems, land uses, markets, and cultural norms. Solutions to water challenges must be sensible to targeted stakeholders (Khosla et al. 2002). Recent developments in modeling and geographic information systems have transformed our ability to link actions at the farm-sized scale with those at the watershed or aquifer scale. Results from the USDA Conservation Effects Assessment Project watershed-scale studies show that water quality benefits of conservation could be substantially improved by targeting practices to those locations that pose the highest risk to critical receiving waters (Jha et al. 2010). 
Incorporate Risk and Uncertainty into Decision Support Strategies. Uncertainty in agricultural water management commonly is addressed in modeling approaches and often translates to risk for producers - as forgone income or increased costs without returns. Improvements in models can reduce or quantify the sources of uncertainty and thereby offer increased confidence in risk-mitigation tools for decision makers and producers. In order to continue advances in modeling and decision support systems, there must be improved data standards, sharing, and interpretation to enhance consistency in the results produced by models. Recent studies in food safety highlight the need for risk-based approaches to address trade-offs between soil and water conservation practices, such as vegetated buffers, and the potential for pathogen transmission from waterborne or mammalian vectors to vegetable crops.

Engage Interdisciplinary Teams. Historically we have invested considerable resources in understanding the physical and biological dimensions of water resource management and neglected investment in understanding human behavior. However, the leadership of experts versed in social sciences, e.g., economics, planning, and behavioral and communication sciences, is essential if we are to motivate behavior change and policies that lead to improved environmental outcomes and enhanced food security. A research prioritization study in the United Kingdom concluded that multidisciplinary approaches and improved dialog and communication between researchers, policy makers, and the public are critical elements of sustainable water management strategies (Brown et al. 2010). By engaging the social sciences, we can more fully understand both market-driven and nonmarket-driven approaches to behavior change. Interdisciplinary approaches are required that focus on constraints to adoption of new practices and the factors that can motivate changes in behavior or policies. The depth and breadth of university-based social science expertise represents a unique but largely untapped asset that can complement programs beyond universities, such as the producer assistance programs of USDA agencies and the private sector. Federal programs can stimulate strategic hires in extension, research, and learning areas by targeting extramural funding for this type of work. Expanding the portfolio of experts engaged in water management can stimulate a range of important outcomes: knowledge is generated through research relevant to end users; knowledge is shared, adapted, tested, applied, and expanded in real contexts; university curricula evolve and are kept current; and the next generation of professionals are trained in interdisciplinary problem solving for their field.

Evaluate Progress, Synthesize Findings, Communicate Solutions, and Adapt Approaches. A recent report from the National Research Council (2012) recommends that water management initiatives include sustained, interactive engagement with stakeholders and have flexibility to adapt to changing conditions. This level of engagement requires a commitment of time and personnel that honors the value of reevaluation and adjustment to improve long-term outcomes. In complex situations of high uncertainty (i.e., wicked problems) a robust evaluation strategy can promote management that adapts to changing conditions and drivers. University extension programs that embody long-term, place-based stakeholder interactions are a natural vehicle to engage in regular and consistent investigations of the progress towards outcomes of watershed-based practices and policies promoted by agencies, researchers, and the private sector. Aggregating the benefits of watershed-scale efforts is not an easy task and requires careful formulation of measurableand meaningful-outcomes.

\section{Conclusions}

Water shortages and water quality problems are prevalent in agricultural watersheds across the United States and internationally, jeopardizing our ability to meet global food needs. Metropolitan areas are growing at unprecedented rates, creating extensive urban, urbanizing, and ex-urban landscapes; putting enormous pressures on limited water supplies; and increasing the risk of conflicts. We identify four grand challenges that, if unsolved, will significantly reduce future agricultural sustainability and productivity. These challenges-nutrient management, food safety, agricultural water use, and groundwater management-must be approached in new ways if we are to move towards solving these problems.

We believe that universities, in particular land-grant universities, are strategically positioned to move society closer to solutions of these problems. Universities can provide expertise and capacity that will complement and improve the outcomes from the work of sister agencies, the private sector, and stakeholder organizations. Bold, concerted investments are required by extramural granting agencies to galvanize approaches that generate meaningful improvements in our nation's waters. Field- and farm-based activities must be viewed from a watershed context that incorporates decision support tools, addresses human dimensions, and engages in evaluations that inform program development. At the heart of these approaches lies a firmer understanding of communication strategies, behavior change, local realities, and community involvement. Funding opportunities that engage the expertise and capacity of land-grant extension programs and social science research with stakeholders are an essential element of efforts that seek to confront the challenges of water management in agricultural, rural, and urbanizing watersheds.

\section{Acknowledgements}

This material is based upon work supported by the National Institute of Food and Agriculture, USDA. Any opinions, findings, conclusions, or recommendations expressed in this publication are those of the author(s) and do not necessarily reflect the view of the USDA. Partial support came from National Science Foundation Grant DEB 1027188.

\section{References}

Akbar, T.A., H. Lin, and J. DeGroote. 2011. Development and evaluation of GIS-based ArcPRZM-3 system for spatial modeling of groundwater vulnerability to pesticide contamination. Computers and Geosciences 37:822-839.

Alberti, M. 2005. The effects of urban patterns on ecosystem function. International Regional Science Review 28:168-192.

Alley, W.M., R.W. Healy, J.W. LaBaugh, and T.E. Reilly. 2002. Flow and storage in groundwater systems. Science 296:1985-1990.

Amador, J.A., D.A. Potts, E.L. Patenaude, and J.H. Gorres. 2008. Effects of depth on domestic wastewater renovation in intermittently aerated leach field mesocosms. Journal of Hydrologic Engineering 13:729-734.

Anderson P., N. Denslow, J.E. Drewes, A. Oliveri, D. Schlenk, and S.A. Snyder. 2010. Monitoring Strategies for Chemicals of Emerging Concern (CECs) in Recycled Water. A report for the State of California - State Water Resources Control Board. Sacramento, CA: State Water Resources Control Board.

AWCC (Agricultural Water Conservation Clearinghouse). 2013. Agricultural Water Conservation Clearinghouse. 
Fort Collins, CO: USDA National Institute of Food and Agriculture, Northern Plains and Mountains Regional Water Program. http://agwaterconservation.colostate. edu/Default.aspx

Barber, M.E., A. Hossain, J. Covert, and G. Gregory. 2009. Augmentation of seasonal low stream flows by artificial recharge in the SpokaneValley-Rathdrum Prairie aquifer of Idaho and Washington, USA. Hydrogeology Journal 17:1459-1470, doi: 10.1007/s10040-009-0467-6.

Bartley, T., and S.N. Smith. 2010. Communities of practice as cause and consequence of transnational governance: The evolution of social and environmental certification. In Transnational Communities: Shaping Global Economic Governance, eds. M.L. Djelic and S. Quack. New York: Cambridge University Press.

Bates, B.C., Z.W. Kundzewicz, S. Wu, and J.P. Palutikof, eds. 2008. Climate Change and Water. Technical paper of the Intergovernmental Panel on Climate Change, IPCC Secretariat. Geneva: Intergovernmental Panel on Climate Change.

Batie, S.S. 2008. Wicked problems and applied economics. American Journal of Agriculture Economics 90:1176-1191.

Beuchat, L.R. 1996. Pathogenic microorganisms associated with fresh produce. Journal of Food Protection 59:204-16.

Bonnie R.J., K. Stratton, and R.B. Wallace. 2007. Ending the Tobacco Problem: A Blueprint for the Nation. Washing $\neg$ ton: National Academies Press.

Brown, L.E., G. Mitchell, J. Holden, A. Folkard, N. Wright, N. Beharry-Borg, G. Berry, B. Brierley, P. Chapman, S.J. Clarke, M. Dobson, E. Dollar, M. Fletcher, J. Foster, A. Hanlon, S. Hildon, P. Hiley, P. Hillis, J. Hoseason, K Johnston, P. Kay, A. McDonald, A. Parrott, A. Powell, R.J. Slack, A. Sleigh, C. Spray, K. Tapley, R. Underhill, and C. Woulds. 2010. Priority water research questions as determined by UK practitioners and policy makers. Science of the Total Environment 409:256-266.

CDC (Centers for Disease Control and Prevention). 1999. Outbreak of Salmonella serotype Muenchen infections associated with unpasteurized orange juice - United States and Canada, July 1999. Morbidity and Mortality Weekly Report 48:582-585.

Clapper, J.R. 2012. Unclassified statement for the record on the Worldwide Threat Assessment of the US Intelligence Community for the Senate Select Committee on Intelligence, January 31, 2012, 39

Conley, D.J., H.W. Paerl, R.W. Howarth, D.F. Boesch, S.P. Seitzinger, K.E. Havens, C. Lancelot, and G.E. Likens. 2009. Controlling eutrophication: Nitrogen and phosphorus. Science 323:1014-1015.

Cowling, E.B., J.W. Erisman, S.M. Smeulders, S.C. Holman and B.M. Nicholson. 1998. Optimizing air quality management in Europe and North America: Justification for integrated management of both oxidized and reduced forms of nitrogen. Environmental Pollution 102:599-608
Custodio, E. 2003. Aquifer overexploitation: What does it mean? Hydrogeology Journal 10:254-277.

de Fraiture, C., M. Giordano, and Y. Liao. 2008. Biofuels and implications for agricultural water use: Blue impacts of green energy. Water Policy10:67-81.

Delgado, J.A., and J.K. Berry. 2008. Chapter 1: Advances in precision conservation. In Advances in Agronomy, vol. 98, ed. D.L. Sparks, 1-44. Amsterdam, the Netherlands: Elsevier Academic Press.

Delgado, J.A.,P.M. Groffman, M.A. Nearing, T. Goddard, D. Reicosky, R. Lai, N. R. Kitchen, C.W. Rice, D. Towery, and P. Salon. 2011. Conservation practices to mitigate and adapt to climate change. Journal of Soil and Water Conservation 66(4):118A-129A, doi:10.2489/ jswc.66.4.118A

Delgado, J.A., R.J. Ristau, M.A. Dillon, H.R. Duke, A. Stuebe, R.F. Follett, M.J. Shaffer, R.R. Riggenbach, R.T. Sparks, A. Thompson, L.M. Kawanabe, A. Kunugi, and K. Thompson. 2001. Use of innovative tools to increase nitrogen use efficiency and protect environmental quality in crop rotations. Communications in Soil Science and Plant Analysis 32:1321-1354

Dobrowolski, J., M. O'Neill, L. Duriancik, and J.Throwe, eds. 2008. Opportunities and challenges in agricultural water reuse: Final report. Washington, DC: USDA Cooperative State Research, Education, and Extension Service.

Dubrovsky, N.M., K.R. Burow, G.M. Clark, J.M. Gronberg, P.A. Hamilton, K.J. Hitt, D.K. Mueller, M.D. Munn, B.T. Nolan, L.J. Puckett, M.G. Rupert, T.M. Short, N.E. Spahr, L.A. Sprague, and W.G. Wilber. 2010. The quality of our Nation's waters: Nutrients in the Nation's streams and groundwater, 1992-2004. USGS Circular 1350.

Emerson, J. 1984. Modeling resource depletion impactsthe Ogallalla aquifer study. Socio-Economic Planning Sciences 18:343-351.

Feaga, J.B., J.S. Selker, R.P. Dick, and D.D. Hemphill. 2010 Long-term nitrate leaching under vegetable production with cover crops in the Pacific Northwest. Soil Science Society of America 74:186-195.

Genskow, K., and L.S. Prokopy. 2010. Lessons learned in developing social indicators for regional water quality management. Society and Natural Resources 23:83-91.

Gold, A.J., W.R. DeRagon, W.M. Sullivan, and J.L. Lemunyon. 1990. Nitrate-nitrogen losses to groundwater from rural and suburban land uses. Journal of Soil and Water Conservation 45:305-310.

Graham, J.L., J.R. Jones, S.B. Jones, J.A. Downing, and T.E. Clevenger. 2004. Environmental factors influencing microcystin distribution and concentration in the Midwestern United States. Water Research 38:4395-4404.

Green, G., and J. Hamilton, 2000. Water allocation, transfers and conservation: Links between policy and hydrology. Water Resource Development 16:197-208.

Groffman, P.M., D.J. Bain, L.E. Band, K.T. Belt, G.S. Brush, J.M. Grove, R.V.Pouyat, I.C.Yesilonis, and W.C. Zipperer.
2003. Down by the riverside: Urban riparian ecology. Frontiers in Ecology and the Environment 1:315-321.

Groffman P.M., A.J. Gold, L. Duriancik, and R.R. Lowrance. 2010. From connecting the dots to threading the needle: The challenges ahead in managing agricultural landscapes for environmental quality. In Managing Agricultural Landscapes for Environmental Quality II: Achieving More Effective Conservation, eds. P. Nowak and M. Schnepf, 1-12. Ankeny, IA: Soil and Water Conservation Society.

Herwaldt, B.L., and M.L. Ackers. 1997. An outbreak in 1996 of cyclosporiasis associated with imported raspberries. The Cyclospora Working Group. New England Journal of Medicine 336:1546-56.

Howarth, R.W., D.M. Anderson, T.M. Church, H. Greening, C.S. Hopkinson, W.C. Huber, N. Marcus, R.J. Naiman, K. Segerson, A. Sharpley, and W.J. Wiseman. 2000. Clean coastal waters: Understanding and reducing the effects of nutrient pollution. Washington, DC: National Academy Press.

Hunter, W.J. 2008. Remediation of drinking water for rural populations. In Nitrogen in the Environment: Sources, Problems, and Management, Second edition, eds.J.L.Hatfield and R.F. Follett.Amsterdam:Academic Press/Elsevier.

Hutson, S.S, N.L. Barber, F.J. Kenny, K.S. Linsey, D.S. Lumia, and M.A. Maupin. 2000. Estimated use of water in the United States in 2000. USGS Circular 1268. Denver, CO: US Geological Survey.

Jha, M.K., K.E. Schilling, P.W. Gassman, and C.F. Wolter. 2010. Targeting land-use change for nitrate-nitrogen load reductions in an agricultural watershed. Journal of Soil and Water Conservation 65(6):342-352, doi: $10.2489 /$ jswc.65.6.342

Joubert, L., P. Hickey, D.Q. Kellogg, and A. Gold. 2004 Wastewater Planning Handbook: Mapping onsite treatment needs, pollution risks and management options using GIS. National Decentralized Water Resources Capacity Development Project. St. Louis, MO: Washington University.

Kellogg, D.Q., A.J. Gold, S. Cox, K. Addy, and P.V August. 2010. A geospatial approach for assessing denitrification sinks within lower-order catchments. Ecological Engineering. 36:1596-160.

Kemper, K.E. 2003. Groundwater: From development to management. Hydrogeology Journal 12(1):3-5, doi: 10.1007/s10040-003-0305-1.

Khosla, R., K.Fleming, J.A. Delgado, T.M. Shaver, and D.G. Westfall. 2002. Use of site-specific management zones to improve nitrogen management for precision agriculture. Journal of Soil and Water Conservation 57:513-518.

Kiang,J.E.,J.R. Olsen, and R. M.Waskom. 2011. Introduction to the featured collection on nonstationarity, hydrologic frequency analysis, and water management. Journal of the American Water Resources Association 47:433-435.

Konikow, L.F., and E. Kendy. 2005. Groundwater depletion: A global problem. Hydrogeology Journal 13:317-320. 
Lal, R., J.A. Delgado, P.M. Groffman, N. Millar, C. Dell, and A. Rotz. 2011. Management to mitigate and adapt to climate change. Journal of Soil and Water Conservation 66(4):276-285, doi:10.2489/jswc.66.4.276.

LeJeune, J.T., T.E. Bessr, and D.D. Hancock. 2001. Cattle water troughs as reservoirs of Escherichia coli O157. Applied Environment and Microbiology 67:3053-57.

Levi, D., and K. Sperry. 2007. Agriculture at the urban interface: Attitudes of new rural residents. Focus: Journal of the City and Regional Planning Department 4: Article 9.

Li, X.X., C.S. Hu, J.A. Delgado, Y.M. Zhang, and Z.Y. Ouyang. 2007. Increased nitrogen use efficiencies as a key mitigation alternative to reduce nitrate leaching in North China Plain Agriculture. Water Management 89:137-147.

Liao, L.X., C.T. Green, B.A. Bekins, and J.K. Bohlke. 2012. Factors controlling nitrate fluxes in groundwater in agricultural areas. Water Resources Research 38: W00L09, doi: 10.1029/2011WR011008.

Lowell, K., and M. Bianchi. 2011. Food safety and surface water quality. In Pesticide Mitigation Strategies for Surface Water Quality, eds. K. Goh, B. Brian, T.L. Potter, and J. Gan. Washington, DC: American Chemical Society.

Lowell, K., J. Langholz, and D. Stuart. 2010. Safe and Sustainable: Co-Managing for Food Safety and Ecological Health in California's Central Coast Region. San Francisco, CA and Washington, DC: The Nature Conservancy of California and the Georgetown University Produce Safety Project.

Mahler, R.L., R. Simmons, and F. Sorensen. 2005. Public perceptions and actions towards sustainable groundwater management in the Pacific Northwest region, USA. International Journal of Water Resources Development 21:465-472.

Marcum, K.B. 2006. Use of saline and non-potable water in the turfgrass industry: Constraints and developments. Agricultural Water Management 80:132-146.

Meinke, H., S.M. Howden, P.C. Struik, R. Nelson, D. Rodriguez, and S.C. Chapman. 2009. Adaptation science for agriculture and natural resource management-urgency and theoretical basis. Current Opinion in Environmental Sustainability 1:69-76.

Morris, J.G. 2011. Cholera and other types of vibriosis: A story of human pandemics and oysters on the half shell. Clinical Infectious Diseases 37:272-80.

Mueller D.K., and N.E. Spahr. 2006. Nutrients in Streams and Rivers Across the Nation. Scientific Investigations Report 2006-5107. Denver, CO: US Geological Survey.

National Research Council. 2012. Challenges and Opportunities in the Hydrologic Sciences. Washington, DC: National Academy Press.

Nguyen-The, C., and F. Carlin. 2000. Fresh and processed vegetables. In The Microbiological Safety and Quality of Food, Volume I, eds. B.M. Lund, T.C. Baird-Parker, and G.W. Gould, 620-684. Gaithersburg, MD: Aspen.

Nolan, B.T., K.J. Hitt, and B.C. Ruddy. 2002. Probability of nitrate contamination of recently recharged ground waters in the conterminous United States. Environmental Science and Technology 36:2138-2145.

Oakley, S. M.,A.J. Gold, and A. J. Oczkowski. 2010. Nitrogen control through decentralized wastewater treatment: Process performance and alternative management strategies. Ecological Engineering 36:1520-1531

Osmond, D.L., N.M. Nadkarni, C.T. Driscoll, E. Andrews, A.J. Gold, S.R. Broussard Allred, A.R. Berkowitz, M.W. Klemens, T.L. Loecke, M.A. McGarry, K. Schwarz, M.L. Washington, and P.M. Groffman. 2010. The role of interface organizations in science communication and understanding. Frontiers in Ecology and the Environment 8:306-313.

Osmond, D.L, N.N. Ranells, S.C. Hodges, R. Hansard, L. Xu, T.E. Jones, and S.H. Pratt. 2001a. Tracking nitrogen loading reductions from agricultural sources: NLEW. In Proceedings of the International Conference on Agricultural Effects on Ground and Surface Waters, Wageningen, The Netherlands, October 1-4, 2000. IAHS Publication 273.

Osmond, D.L., L. Xu, N.N. Rannels, S.C. Hodges, R. Hansard, L. Xu, T.E. Jones, and S.H. Pratt. 2001b. Nitrogen loss estimation worksheet (NLEW): An agricultural nitrogen loading reduction tracking tool. In Optimizing nitrogen management in food and energy reduction and environmental protection: Proceedings of the 2nd International Nitrogen Conference on Science and Policy. Scientific World 1.

Postel, S.L., G.C. Daily, and P.R. Ehrlich. 1996. Human appropriation of renewable fresh water. Science 271:785-788.

Postma, F.B.,A.J. Gold, and G.W. Loomis. 1992. Nutrient and microbial movement from seasonally used septic systems. Journal of Environmental Health 55:5 10.

Rittel, H.W.J., and M. Webber. 1973. Dilemmas in a general theory of planning. Policy Sciences 4:155-159.

Robinson, K.G., C.H. Robinson, and S.A. Hawkins. 2005 Assessment of public perception regarding wastewater reuse.Water Science Technology and Water Supply 5:59-65.

Scallan, E., P.M. Griffin, FJ.Angulo, R.V.Tauxe, and R.M. Hoekstra. 2011b. Foodborne illness acquired in the United States: Unspecified agents. Emerging Infectious Diseases 17:16-22.

Scallan, E., R.M. Hoekstra, F.J. Angulo, R.V. Tauxe, M.A.Widdowson, S.L. Roy, J.L. Jones, and P.M. Griffin. 2011a. Foodborne illness acquired in the United States: Major pathogens. Emerging Infectious Diseases 17:7-15.

Schaible, G. 2000. Economic and conservation tradeoffs of regulatory vs. incentive-based water policy in the Pacific Northwest. Water Resource Development 16:221-238.

Schipper L.A., W.D. Robertson, A.J. Gold, D.B. Jaynes, and S.C. Cameron. 2010. Denitrifying bioreactors: An approach for reducing nitrate loads to receiving waters. Ecological Engineering 36:1532-43.

Scibek, J., and D.M. Allen. 2006. Modeled impacts of predicted climate change on recharge and groundwater levels. Water Resources Research 42:W11405, doi:10.1029/2005WR004742.

Smith, T.A., D. Osmond, and J.W. Gilliam. 2006. Riparian buffer width and nitrate removal in a lagoon-effluent irrigated agricultural area. Journal of Soil and Water Conservation 61:273-281.

Sophocleous, M. 2010. Review: Groundwater management practices, challenges, and innovations in the High Plains aquifer, USA: Lessons and recommended actions. Hydrogeology Journal 18:559-575.

Strzepek, K., D. Major, C. Rosenzwieig, A. Iglesias, D.Yates, A. Holt, and D. Hillel. 1999. New methods of modeling water availability for agriculture under climate change: The US Cornbelt. Journal of the American Water Resources Association 35:1639-1655.

Sutton, M.A., S. Reis, G. Billen, P. Cellier, J.W. Erisman, A.R. Mosier, E. Nemitz, J. Sprent, H. van Grinsven, M. Voss, C. Beier, and U. Skiba. 2012. Nitrogen and global change. Biosciences 9:1691-1693.

Thurston-Enriquez, J.A., J.E. Gilley, and B. Eghball. 2005. Microbial quality of runoff following land application of cattle manure and swine slurry. Journal of Water and Health 3:157-171.

Tilman, D., K.G. Cassman, P.A. Matson, R. Naylor, and S. Polasky. 2002. Agricultural sustainability and intensive production practices. Nature 418:671-677.

UN DESA (United Nations Department of Economic and Social Affairs). 2010. World Population Prospects: The 2010 Revision. New York: Population Division of the Department of Economic and Social Affairs.

US Department of Health and Human Services. 2010. How Tobacco Smoke Causes Disease: The Biology and Behavioral Basis for Smoking-Attributable Disease: A Report of the Surgeon General. Rockville, MD: Public Health Service, Office of the Surgeon General.

Vecchia, A.V., R.J. Gilliom, D.J. Sullivan, D.L. Lorenz, and J.D. Martin. 2009. Trends in concentrations and use of agricultural herbicides for Corn Belt rivers, 1996-2006. Environmental Science and Technology 43:9096-9102.

Waskom, R., and J. Kallenger. 2009. Graywater Reuse and Rainwater Harvesting. Colorado State Extension Fact Sheet. Fort Collins, CO: Colorado State University Extension.

Waskom R., J. Pritchett, and J. Schneekloth. 2006. Outlook on the High Plains aquifer: What's in store for irrigated agriculture? Great Plains Soil Fertility Conference, Proceedings, Denver, Colorado, March 2006, 122-128.

Winter, T.C., J.W. Harvey, O.L. Franke, and W.M. Alley. 1998. Ground water and surface water: a single resource. US Geological Survey Circular 1139. Denver, CO: US Geological Survey, Branch of Information Services.

WEF (World Economic Forum). 2009. The bubble is close to bursting:A forecast of the main economic and geopolitical water issues likely to arise in the world during the next two decades. Draft for Discussion at the World Economic Forum Annual Meeting 2009, World Economic Forum.

WEF. 2011. Water Security: The Water-Food-EnergyClimate Nexus. Washington, DC: Island Press. 